Regards sur l'économie allemande

Bulletin économique du CIRAC

118-119| 2015

Varia

\title{
Société civile
}

Deutsch-Französisches Institut (Hrsg.), Frankreich Jahrbuch 2014 Zivilgesellschaft in Frankreich, Deutschland und Europa

Solène Hazouard

\section{(2) OpenEdition}

12 Journals

Édition électronique

URL : http://journals.openedition.org/rea/4945

DOI : $10.4000 /$ rea. 4945

ISSN : 1965-0787

Éditeur

CIRAC

\section{Édition imprimée}

Date de publication : 31 décembre 2015

Pagination : 47

ISSN : 1156-8992

\section{Référence électronique}

Solène Hazouard, « Société civile», Regards sur l'économie allemande [En ligne], 118-119 | décembre 2015, mis en ligne le 31 décembre 2015, consulté le 25 septembre 2020. URL : http:// journals.openedition.org/rea/4945; DOI : https://doi.org/10.4000/rea.4945

Ce document a été généré automatiquement le 25 septembre 2020.

(c) CIRAC 


\section{Société civile}

Deutsch-Französisches Institut (Hrsg.), Frankreich Jahrbuch 2014 Zivilgesellschaft in Frankreich, Deutschland und Europa

\section{Solène Hazouard}

\section{RÉFÉRENCE}

Deutsch-Französisches Institut (Hrsg.), Frankreich Jahrbuch 2014 - Zivilgesellschaft in Frankreich, Deutschland und Europa, Coll. Research, Springer VS, Wiesbaden, 2015,244 p.

Dans la dernière édition de son Frankreich Jahrbuch, l'Institut franco-allemand de Lubwigsburg propose un grand dossier thématique sur la société civile en France, en Allemagne et en Europe. Un article de Christine Quittkat, du Mannheimer Zentrum für Europäische Sozialforschung (Centre de recherche sociale européenne de Mannheim), y traite de la défense des interêts des associations professionnelles françaises au niveau européen, tandis que Patrick Hassenteufel, de l'université Versailles Saint-Quentin, et Louise Lartigot-Hervier, du Laboratoire interdisciplinaire d'évaluation des politiques publiques à Sciences Po, offrent une comparaison France-Allemagne de l'évolution du rôle des acteurs non gouvernementaux dans les systèmes de protection sociale. En marge de ce dossier, Henrik Uterwedde revient sur ses 40 ans passés au service de la coopération franco-allemande, notamment en tant que directeur adjoint de l'Institut franco-allemand de Ludwigsburg. 